\title{
E-Participation in Local Government: Case of Ankara Metropolitan Municipality*
}

\author{
Yerel Yönetimlerde E-Katılım: Ankara Büyükşehir Belediyesi Örneği
}

\author{
Harika UÇAR \\ Dr. Öğr. Gör., Ankara Hacı Bayrm Veli Üniversitesi, \\ Tapu KadastroYüksekokulu, harika.ucar@hbv.edu.tr \\ https://orcid.org/0000-0001-7438-7496
}

\section{ArI CANSEL}

Doç. Dr., Ankara Hacı Bayram Veli Üniversitesi, Tapu Kadastro Yüksekokulu, aril.cansel@hbv.edu.tr https://orcid.org/0000-0002-4991-0326
Makale Başvuru Tarihi: 22.01.2021

Makale Kabul Tarihi: 21.04.2021

Makale Türü: Araştırma Makalesi

\begin{abstract}
Anahtar
Kelimeler:

Mobil Katılım

Mobil Yönetim,

Mobil Belediye Uygulamaları,
\end{abstract}

Keywords:

Mobile

Participation,

Mobile Government,

Mobile Municipality Apps,

\section{ÖZET}

Kentler, ekonomik, sosyal, kültürel, teknolojik ve politik faktörlerin değișimlerinden etkilenirler. Kent yönetimine katılım bağlamında vatandaşların bu sürece uyum sağlayacak yöntemler geliş̧tirmesi ve bu değişimin bir parçası olması önemlidir. Bu bağlamda yerel yönetimlerde dijital teknoloji kullanımı artırllabilir ve vatandaşların karar alma süreçlerine katılımı da teknolojik altyapı gelişimine bağlantılı olarak artırılabilir. Bu çalışmada, Ankara Büyükșehir Belediyesi'nin dijital dönüşüm süreci; en yeni mobil uygulaması Başkentmobil'i de kapsayan bir vaka olarak tanıtılmıştır. Demokratik yönetişim, şeffaflı, katılım ve hesap verebilirlik gibi kavramlarla birlikte sunulan uygulamanın ilk aşaması Belediye başkanı tarafindan tanıtılmıştır. Belediye başkanı ayrıca, uygulamanın büyük ölçüde belediye için çalışan uzmanlar tarafindan geliştirildiğini belirtmektedir. Uygulama halen işlevseldir ve ikinci aşaması tamamlanmak üzeredir. Bu çalışma, Ankara Büyükşehir Belediyesi'nin mobil belediyeye dönüşme çabalarını bilimsel veriler ışı̆̆ında değerlendirmeyi amaçlamaktadır.

\section{ABSTRACT}

Cities are affected by changes in the economic, social, cultural, technological and political factors. In the context of participation in the management, it is important that citizens develop methods to adapt to this process and become a part of this change. In this context, the use of digital technology in local governments can be increased. Citizens' participation in decision-making processes can also be increased depending on the development of technological infrastructure. In this study, Ankara Metropolitan Municipality's digital transformation process is introduced as a case covering the recent history and the newest mobile app Başkentmobil. The first phase of the application introduced by the mayor along with concepts such as democratic governance, transparency, participation, and accountability. The mayor also mentioned that most of the app was developed by the specialists working for the municipality. The app was launched, and the second phase will be completed in June. This study aims to evaluate the Ankara Metropolitan Municipality's efforts to transform into mobile municipality in the light of scientific data.

\footnotetext{
This study is the expanded version of the paper presented at the "The International Symposium on Business and Economics-ISBE 2020 " on June 04-05.
} 


\section{INTRODUCTION}

Computer has become an integral part of our lives. The internet has entered and changed the way we live and work forever. The transformation is speeding up. Digital technologies are changing our experiences to a great extent. Just like the transportation technologies once expanded the mobility of humans or communication technologies zeroing the distance between places. Generations who are born in the digital transformation era create a new lifestyle with their way of interpreting the digital world, their relationship with artificial intelligence, their awareness and knowledge of new media technologies and their ability to use the digital world (Demiral, 2018:19).

The participation of individuals in the city management takes place in two forms, namely political and administrative. Political participation can be expressed as the political participation of individuals and groups in order to choose political leaders at national and local level and to enable them to make decisions in line with their own wishes and interests. The most known forms of political participation are voting in elections, participating in election campaigns and demonstrations (Dursun, 2004:231). However, citizens are increasingly questioning traditional forms of representative democracy and expecting innovation in policy-making processes with possibilities of direct participation. This is mainly due to the challenges democratic countries are facing, such as the gap between the political elites and the citizens, which leads to the problem of political disengagement. There is a need to revive democratic societies and to enhance a more deliberative view of active citizenship through more direct engagement (EU Parliament, 2016:12).

Administrative involvement is the contribution of those who will be directly or indirectly affected by one, several or all of the stages of preparation, maturation, conversion and implementation of basic decisions related to public services, apart from election and electoral activities. Thanks to the accession process, administration involves citizens in the process of public policy making; listens to their problems, demands and thoughts; it takes into account their thoughts and reactions in their decisions (Ery1lmaz, 2019:62-63).

Barber (1995) states that citizens, who are more likely to watch than to play, are playing the role of "watchman" and are not different from the audience who fall asleep while watching a bad movie (Barber, 1995:165-167). Effective citizens, not spectator citizens, are required to achieve strong democracy. The participation of citizens should not be limited to political participation, but the necessary mechanisms should be developed to ensure administrative participation as well. Contemporary democracies are social and managerial regimes in which the people can continuously influence and control decision mechanisms and administrative activities in all matters other than elections where people shape the area they live in, and where this tradition becomes a way of life (Palabiyık and Görün, 2004:262). Municipalities continue to be the first order of government, the one closest to the citizens; However, in the developing world these organizations still show severe deficiencies in technology literacy, which in turn avoids the inclusion of their citizens, and the elaboration of public policies (GutierrezDiez et al., 2018:28). In order to reach beyond that paradigm, it is necessary to ensure a real public participation by keeping the channels of participation open for all layers of the society. The democratic principles and values such as citizens' involvement, the power of majority, the leaders' commitment to interaction and accountability towards voters are also valid on the local scale (Keleş, 2006:45).

In parallel with the technological development, the digital elections have been discussed with their positive and negative aspects. However, since participation is not only about voting in the elections, it is obvious that citizens would be made more effective by the digitalization of administrative participation. As a matter of fact, the desire of the citizens to participate in the administration increases and evolves in quality with the changing environmental factors. However, to achieve digital participation, access to technological opportunities for citizens should be easy, the necessary infrastructure should be provided, and beyond that, citizens should have the necessary level of awareness and education to use the participation channels offered.

Recently mobile phone penetration in Turkey, surpasses the computer and Internet penetration rates. The use of mobile broadband connection surpasses the land broadband connection. The desire of individuals to benefit from information and communication technologies on the go has increased the demand for mobile technologies. In this context, mobile device ownership has become widespread and access to the Internet has shifted to mobile. Under these conditions it can be predicted that mobile technologies will be the most preferred technology in egovernment service delivery in the near future. When evaluating the "mobile state" (m-state) the changetransformation oriented view should be preferred rather than the technological focus that considers the m-state 
solely consists of mobile technologies. According to the change- transformation-oriented view (Gürses and Engin, 2016:225-226) m-state is defined as "Working independent of time and space in wireless and virtual environments, bringing resources together in the virtual environment to provide organizational structuring and functioning that will enable production and presentation in the virtual environment".

\section{LOCAL GOVERNMENT AND DIGITAL TRANSFORMATION}

Within the structure of public administration, the closest administrative units to the public are local administrations. Local governments in Turkey; consist of municipalities, villages, special provincial administrations and metropolitan municipalities (established in 1984). This study is mainly based on municipalities and specifically on Ankara Metropolitan Municipality.

Local governments attempt to keep pace with digital transformation by knowing that the classical representation democracy is insufficient in responding to the needs of different public segments today. They are becoming increasingly effective and efficient with new qualities and functions in servicing the democratic tendencies as the people want to actively participate in the decision making and administrative processes more than ever (Öktem, 2005:54). The spread of mobile applications stands out as the main element in this transformation. It is clear that m-municipal practices are a very convenient tool for local governments to fulfill their functions in terms of both service and democracy in the most effective and efficient way and to ensure citizen satisfaction. "Municipalities", as "school of democracy", are now taking the "school of e-government" role, with smaller span and to be based on direct relationships with public (Şat, 2009). Enabling local governments to benefit from mobile technologies increases service quality, decreases service costs to reach citizens, speeds up the negotiation process with citizens while determining service policies. Involving citizens in decision making processes with mobile applications will enable democracy to flourish (Gürses and Engin, 2016:232; Karaca and Öztürk, 2019:529).

Fig. 1. Municipal Focus Areas

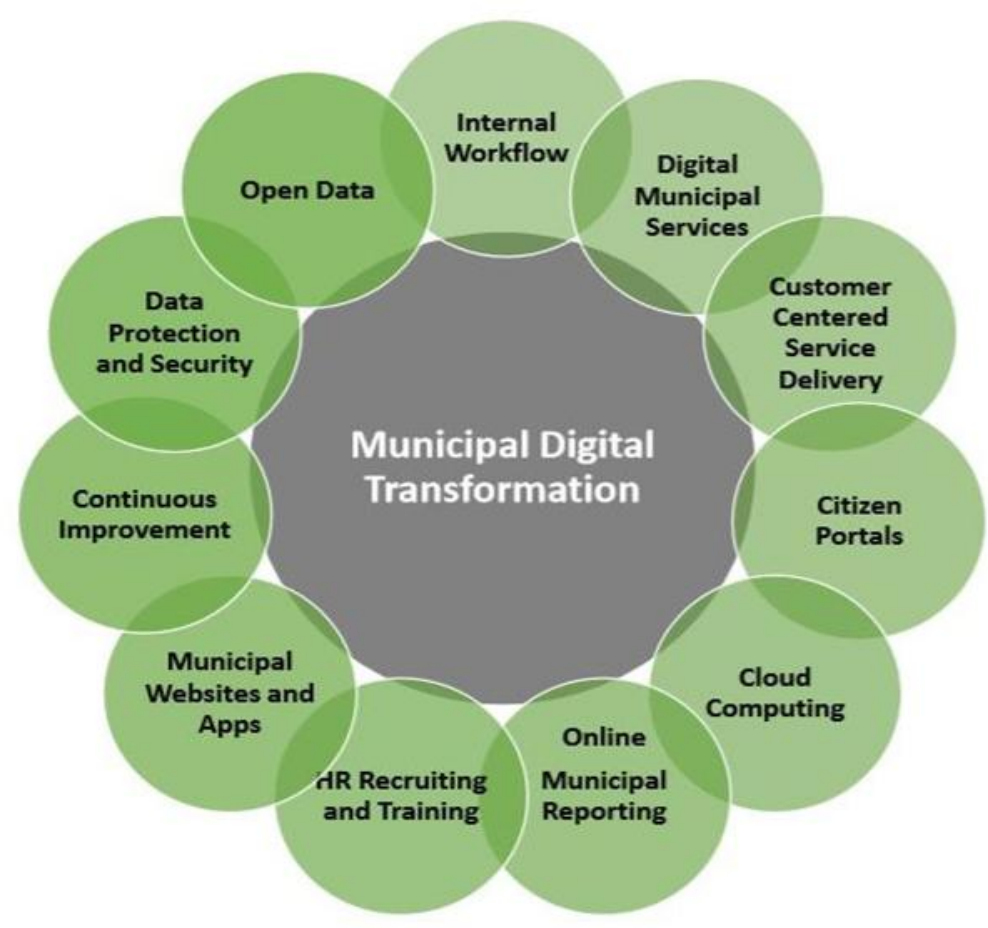

Source: Murphy et al., 2018:8.

Transformational municipalities develop a digital backbone by focusing on technology supported services as shown above. This process of digitalization creates a good platform for the municipalities and their publics to practice direct democracy. However, the level of skill requirements increase for everyone involved in the process. 


\section{E-MUNICIPALITY, E-PARTICIPATION AND M-PARTICIPATION}

People should be able to express their opinions on all matters concerning themselves and the society they live in, participate in decision-making processes, and seek their rights in local and central governments. Local administrations aiming to fulfill the demands and needs of the local people should aim to realize the governance that symbolizes the participatory, accountable, transparent and customer satisfaction-oriented management approach of our era (Henden and Henden, 2005:49). In this context, the demands for the reconstruction of democracy on a more participatory basis that is defined as the participation of the people in the administration, are also increasing rapidly. "E-democracy", "digital democracy", "online democracy", associated with the use of common electronic tools and it leads to the emergence of a phenomenon such as "cyber democracy" based on the participation of citizens (Uçkan, 2003:26-27).

Fig. 2. Model Development of Municipal E-Services

\begin{tabular}{|c|c|c|}
\hline \multirow{16}{*}{$\begin{array}{l}\text { Increased level of } \\
\text { complexity }\end{array}$} & \multirow[t]{7}{*}{ Transaction } & Mobile \\
\hline & & Online Transaction \\
\hline & & Follow Up (Monitoring) \\
\hline & & Digital Certificate \\
\hline & & Citizen Folder \\
\hline & & Online Payments \\
\hline & & Personalization \\
\hline & \multirow[t]{2}{*}{ Interaction } & Email \\
\hline & & Telephone Listings \\
\hline & \multirow[t]{2}{*}{ Urban Information } & Street Map \\
\hline & & Transportation \\
\hline & \multirow[t]{4}{*}{ Municipal Presence } & Applications (Document downloads) \\
\hline & & Council/Municipal Newsletter \\
\hline & & Browser/Search Engine \\
\hline & & Web Map \\
\hline & Dimension & Municipal e-service \\
\hline
\end{tabular}

Source: Morales and Bayona, 2019:52.

Above figure shows the relationship between the technological complexity of services offered by municipalities and progressive stages towards e-democracy. However, depending on the municipality and the community it is in the relationship may not be a linear one at all times.

The benefits of e-municipality applications can be listed as follows (Henden and Henden, 2005:59);

1. The management and decision-making process becomes transparent.

2. Time and space limitations in the service can be eliminated. 
3. A decrease in service costs can be observed for the institution and the local community.

4. Stakeholder spirit will be emerged, and a participatory understanding will be started to settle in the local community due to urban consciousness. Important progress will be made in the democratization process.

5. As the citizens taking more responsibility in completing their own local government tasks, the common excessive employment problem in local governments can be eliminated.

6. The dissemination of participation and progress tracking may increase the quality of services provided.

7. In terms of integration with the world; an increase in the number of e-municipal applications will cause an increase in the use of information technologies by the public.

8. Thanks to the citizen-oriented perspective in service delivery, public confidence in local governments can be observed.

The idea of mobile-state ( $\mathrm{m}$-state) has emerged with the increasing popularity and use of mobile phones with mobile tools that provide better access to public information and services over the Internet increasing the opportunity for participation in management (Y1ld1z, 2006:258). E-government through $\mathrm{m}$-state provides users an uninterrupted access to the public information and service delivery that is normally limited with working days and hours. It is now possible to access public information and services anytime and anywhere, 365 days a year, 24 hours a day. In that sense, the mobile state can be seen as a supplement or integrator rather than an alternative to electronic state applications. In other words, the mobile state means "e-government with added value" (Y1ldiz, No date:1).

The m-participation is becoming an important tool in the progress of democracy. The term m-participation is used to describe participation via mobile devices such as smartphones and tablets quite similar to e-participation which is defined as "the use of ICT to support... democratic decision-making processes". General potentials of m-participation listed in the academic literature include (Schroder, 2014: 2);

- The facilitation of instant communication, interaction and support between groups and individuals and thus being more productive and responsive

- The provision of better quantitative and qualitative data on individual lifestyles and choices and

- The strengthening of the role of "citizen planners".

Almost all municipalities in Turkey involved with digital conversion to respond to the expectations and demands of their public. All have created websites and social media accounts. However, digital municipality has a meaning beyond the municipalities introducing themselves through a website and making inquiries in property tax, water invoice, building permit without going to the city hall (Karaca and Öztürk, 2019:531).

According to Bojang and Bwango (2018), public engagement and acceptance of e-Services are still an issue in many developing countries including Turkey where public participation through e-Municipality is still low. Although some improvements were witnessed many people in Turkey still prefer the traditional means of engaging the local government. Digital literacy may be a factor to blame but Lee's study on the motivational factors for e-democracy participation shows that there is a strong co-relation between weak off-line social networks and motivation to participate in e-democracy process (2014). Turkish society thrives on both off-line and on-line networking and that may be an explanation why people respond slowly to the on-line participation opportunities.

\section{GLOBAL EXAMPLES OF E-DEMOCRACY, E-PARTICIPATION AND E-MUNICIPALITY}

The "virtual senator" application in Chile that is implemented in 2012 is an original and interesting example where the representation, participation, supervision and surveillance functions are carried out through eparliament. In this system in addition to lawmakers and, senators, Chilean citizens who want to vote on decisions that are to be made in the parliament can also register themselves as virtual senators. Chilean citizens can sign up for the "virtual senator" system in their parliament if they wish. Registered users can obtain information about the draft laws, similar to the favorable and unfavorable voting grounds of senators. They can vote virtually about the draft and convey their opinions and suggestions. The results are announced to the public 
and to the lawmakers. Then a new draft is written, or the final version of the draft is being voted (Yildiz, $2017: 25)^{* *}$.

There are a growing number of e-participation models in other countries and they present large similarities between them in terms of development stages. The Open Government Partnership (OGP) was established in 2011 to help level the countries in speed of e-democracy progress. In order to achieve that objective the OGP organized itself to secure commitments from national and sub-national governments to promote open government, empower citizens, fight corruption, and harness new technologies to strengthen governance. The OGP today has 78 member states and focuses on to "support and encouragement to countries around the world as they champion ambitious new reforms and deliver on their promises under the watchful eyes of citizens" (Dudman, 2012). Moreover (Lironi, 2016:30),

"the UN has been assessing e-participation performances since 2003 and comes up with a ranking of countries, following its e-participation index, every two years. The OECD analyses more specific digital tools used by citizens in order to participate in policy-making under its e-government framework. More recently, the EU has also been working on its own Digital Economy and Society Index, and ranks countries according to certain performances such as connectivity, digital skills and online public services".

The table above shows the results of research on Latin American municipalities by ranking and comparing them against more advanced country experiences. Their findings show that most Latin American countries are in digital interaction or digital transaction stages (Bayona and Morales, 2016). However, Finland being the leading e-democracy country in the World most developed countries generally report full e-democracy integration.

Table 1. Development Stages of E-Democracy in Various Countries

\begin{tabular}{|c|c|c|c|c|c|c|}
\hline \multirow{2}{*}{$\begin{array}{c}\text { MODEL OF } \\
\text { E-GOVERNMENT }\end{array}$} & \multicolumn{6}{|c|}{ FEATURES } \\
\hline & STAGE 1 & STAGE 2 & STAGE 3 & STAGE 4 & STAGE 5 & E-SERVİCES \\
\hline Baum y Di Mario (2000) & $\begin{array}{l}\text { Online } \\
\text { Presence }\end{array}$ & Interaction & Transaction & $\begin{array}{l}\text { Transformation or } \\
\text { e-Democracy }\end{array}$ & - & $\mathrm{n} / \mathrm{e}$ \\
\hline Layne y Lee (2001) & Catalogue & Transaction & $\begin{array}{l}\text { Vertical } \\
\text { Integration }\end{array}$ & $\begin{array}{l}\text { Horizontal } \\
\text { Integration }\end{array}$ & - & 9 \\
\hline $\begin{array}{l}\text { PPR Model - Reconstruction } \\
\text { Process Public Sector }\end{array}$ & Cultivation & Extension & Maturity & Revolution & - & - \\
\hline $\begin{array}{c}\text { Accenture 2003, Grupo Gartner y } \\
\text { Comisión Europea }\end{array}$ & Presence & $\begin{array}{l}\text { Urban } \\
\text { Information }\end{array}$ & Interaction & Transaction & E-Democracy & $\mathrm{n} / \mathrm{e}$ \\
\hline José Esteves (2005) & Presence & $\begin{array}{c}\text { Urban } \\
\text { Information }\end{array}$ & Interaction & Transaction & E-Democracy & $\mathrm{n} / \mathrm{e}$ \\
\hline United Nations (UN) & Emerging & Improved & Transactional & Connected & - & $\mathrm{n} / \mathrm{e}$ \\
\hline Expanded UN & $\begin{array}{l}\text { Emerging } \\
\text { Presence }\end{array}$ & $\begin{array}{l}\text { Enhanced } \\
\text { Presence }\end{array}$ & $\begin{array}{l}\text { Interactive } \\
\text { Presence }\end{array}$ & $\begin{array}{c}\text { Transactional } \\
\text { Presence }\end{array}$ & $\begin{array}{c}\text { Full } \\
\text { Integration }\end{array}$ & $\mathrm{n} / \mathrm{e}$ \\
\hline $\begin{array}{c}\text { Model Development of } \\
\text { Municipal e-Services in Spain }\end{array}$ & Presence & $\begin{array}{c}\text { Urban } \\
\text { Information }\end{array}$ & Interaction & Transaction & e-Democracy & 16 \\
\hline $\begin{array}{l}\text { Development Model Municipal } \\
\text { e-Government in Venezuela }\end{array}$ & Presence & $\begin{array}{l}\text { Urban } \\
\text { Information }\end{array}$ & Interaction & Transaction & e-Democracy & 17 \\
\hline $\begin{array}{c}\text { Analysis Model Municipal Web } \\
\text { Pages in Argentina }\end{array}$ & Presence & $\begin{array}{l}\text { Urban } \\
\text { Information }\end{array}$ & Interaction & Transaction & e-Democracy & 26 \\
\hline $\begin{array}{l}\text { Extended Maturity Model. } \\
\text { Government of Australia }\end{array}$ & $\begin{array}{c}\text { Web } \\
\text { Presence }\end{array}$ & $\begin{array}{c}\text { Access } \\
\text { Information }\end{array}$ & $\begin{array}{l}\text { Transaction } \\
\text { Processing }\end{array}$ & $\begin{array}{l}\text { Maximize The } \\
\text { Value of The } \\
\text { Organization }\end{array}$ & - & $\mathrm{n} / \mathrm{e}$ \\
\hline $\begin{array}{l}\text { Darrell M. West (2007) Applied } \\
\text { in Mexico }\end{array}$ & Billboards & $\begin{array}{l}\text { Partial } \\
\text { Services }\end{array}$ & $\begin{array}{l}\text { Executable and } \\
\text { Integrated }\end{array}$ & $\begin{array}{l}\text { Interactive } \\
\text { Democracy }\end{array}$ & - & 46 \\
\hline
\end{tabular}

Source: Bayona and Morales, 2016: 54.

\footnotetext{
** For detailed information: https://www.senadorvirtual.cl/proyectos (Date of access: 03.08.2020).
} 


\section{ANKARA METROPOLITAN MUNICIPALITY APPLICATIONS}

The Covid 19 outbreak highlighted the importance of digitalization more than ever. Many people, from politicians to academics, journalists to lawyers, believe that the humanity is no longer going to return to the societal norms that existed before the outbreak, and the humanity is now going through a transformation. In this context, citizens can receive education, work and entertain without leaving their homes and receive many services from both the private sector and the public through mobile applications. Under the circumstances it is inevitable that the political participation channels of the citizens become mobile. Many municipalities have taken steps in this regard before this process. In Turkey, large or small all municipalities have websites. Although they have their differences in functionality, many of them provide some information and services related to e-government through these web addresses. In addition to providing information and services, local governments use e-municipality and m-municipal services to provide e-participation, supervision, transparency and accountability in terms of democratic participation. Ankara Metropolitan Municipality Website is in a digital transformation process with its recently introduced and implemented social media accounts and mobile applications. Transparency, participation and accountability have been prioritized with the introduced mobile application with the emphasis on democratic governance (Ankara Metropolitan Municipality, 2020).

In this study, Başkent Mobil (Capitol Mobile) application and other activities of Ankara Municipality were evaluated. The experienced pandemic limitations were also reflected in the study. Although it was planned to have a meeting with municipality staff before the outbreak the fact of the matter is face to face communication is not necessary to see the functionality of the website and mobile application.

The citizens who participate in a democratic process must have equal opportunity to access the available information, necessary technical infrastructure to participate and a sufficient level of awareness to understand, judge and contribute to the issues in hand. We take a look at the Ankara Metropolitan Municipality services with the pre-acceptance of municipalities reaching a larger population of people with speed and convenience of e-municipality practices (Gürler Hazman, 2005:66). Although the number of followers of the Facebook account is not visible, the number of people who liked the page is 100,000 and the number of followers of the Twitter account is limited to 4.586. More than 100.000 users have downloaded Başkent mobile application on their smart devices. According to census data, the 2019 population of Ankara was 5.650 .000 (non-Turkish citizens and tourists are not included). People using digital facilities of the Ankara Metropolitan Municipality can be considered a limited segment. The participants are citizens who actively use the internet and monitor the activities of the municipality there. It should be aimed to reach all Ankara residents with the aforementioned social media applications on the internet. Informative and encouraging activities may be required to ensure participation of over 65 years old. After locking down the 65+ and restricting them of intercity traveling throughout the pandemic the government offered them an emergency travel document for limited situations. It turns out that most 65+ citizens have not been able to get their documents over the internet. Support can be provided by volunteers for over $65+$ years of age to use e-participation channels. The volunteers, who are likely to be their children, grandchildren, and neighbors. The Municipality demonstrates its sensitivity for the disabled with the "Disabled People Module" added to the capital mobile application in order to keep the participation channels open to all citizens in the digital applications. As this module is recommended and put into practice by the Visually Impaired Association It should be considered a positive example of participation as well (Yildiz M., 2020:6). Y1ldiz states that citizens can e-participate in metropolitan municipalities in the process of agenda / problem determination, planning, decision making, implementation and evaluation stages of issues. Since the Başkent Mobil application of Ankara Metropolitan Municipality is not yet completed and contains applications complementing the website, it would be necessary to examine the website.

\subsection{Ankara Metropolitan Municipality Website ${ }^{1}$}

Ankara Metropolitan Municipality has come online in 1996 and published its web site in 1997 (Kaya Bensghir, 2000:85). Ankara Metropolitan Municipality provides information on: News, tender announcements, events, weather information, current state prices, disaster gathering areas, grocery store list serving over 65 years of age in the pandemic process, as well as photo and video galleries, environmental and landscape academy, cemetery information system, transportation information system, Ankara Police, Ankara Fire Department (Alo 112) and e-declaration links. In the link of the Academy of Environment and Landscape, park garden care training,

1 (https://www.ankara.bel.tr) 
garden and balcony design, sapling / flower production and maintenance processes, information about plants adapted to Ankara climate are prepared with guides, lecture notes, books and videos, and suggestions for evaluating the process of staying at home are presented. Apart from the information, news and events related to the classical organization structure, the Ankara Police House link contains examples of petitions that may be required for citizens. Through the E-Declaration Transactions link, transactions such as registry inquiry, online collection / debt inquiry, receipt breakdown, chimney cleaning form, fire prevention measure report, online advertisement declaration of advertisement can be performed.

The Transparency and Accountability link contains parliamentary activities, strategic management tools, audit reports, tender and purchase reports, outreach and service reports, financial reports and statements. With the Ankara Web TV application, a significant step was taken in terms of transparency by live broadcasting and recorded videos for tender and parliamentary meetings, news, culture / art and environment programs. City council meetings and tenders are also broadcasted live on social media accounts. In addition to the ability to send messages to the mayor in almost all municipalities, the "Click and Speak" application aimed to ensure that citizens can directly access municipal officials. These practices are aimed to ensure e-participation of citizens in the form of agenda and problem determination.

Campaigns were organized during the Covid 19 Epidemic and Ramadan. Paying the invoices on behalf of the needy, filling their transportation cards, giving an iftar dinner and cash contributions are delivered through mobile applications. Making a contribution is explained by step-by-step instructions. The number, amount and final status of the contributions provided were updated and shared. This application is an example to be considered both in terms of measuring and evaluating applications and in terms of transparency and accountability. Kaya Bensghir's study in 2000 revealed that the essential services such as obtaining the opinion of the public for decision making process and providing cooperation of the public in service design were missing. It seems that the municipality has come a long way in this regard in 20 years.

\subsection{Başkent Mobil (Capitol Mobile)}

The recently introduced mobile application of Ankara Metropolitan Municipality was launched by the Mayor along with concepts such as democratic governance, transparency, participation and, accountability. The first phase of the application was mostly developed by the staff working in the municipality. The second phase will be completed in June. We see that many applications on the web page are also active on Başkent mobile.

As soon as the application is launched, the current information on the social aid campaign on the web page was available under the title of Solidarity Platform. Assistance can also be provided through the mobile application by easily filling a request form. As the requests are approved help is available in various forms. The current status information of the campaign is also shared on the mobile application.

Fig. 3. Solidarity Platform I.
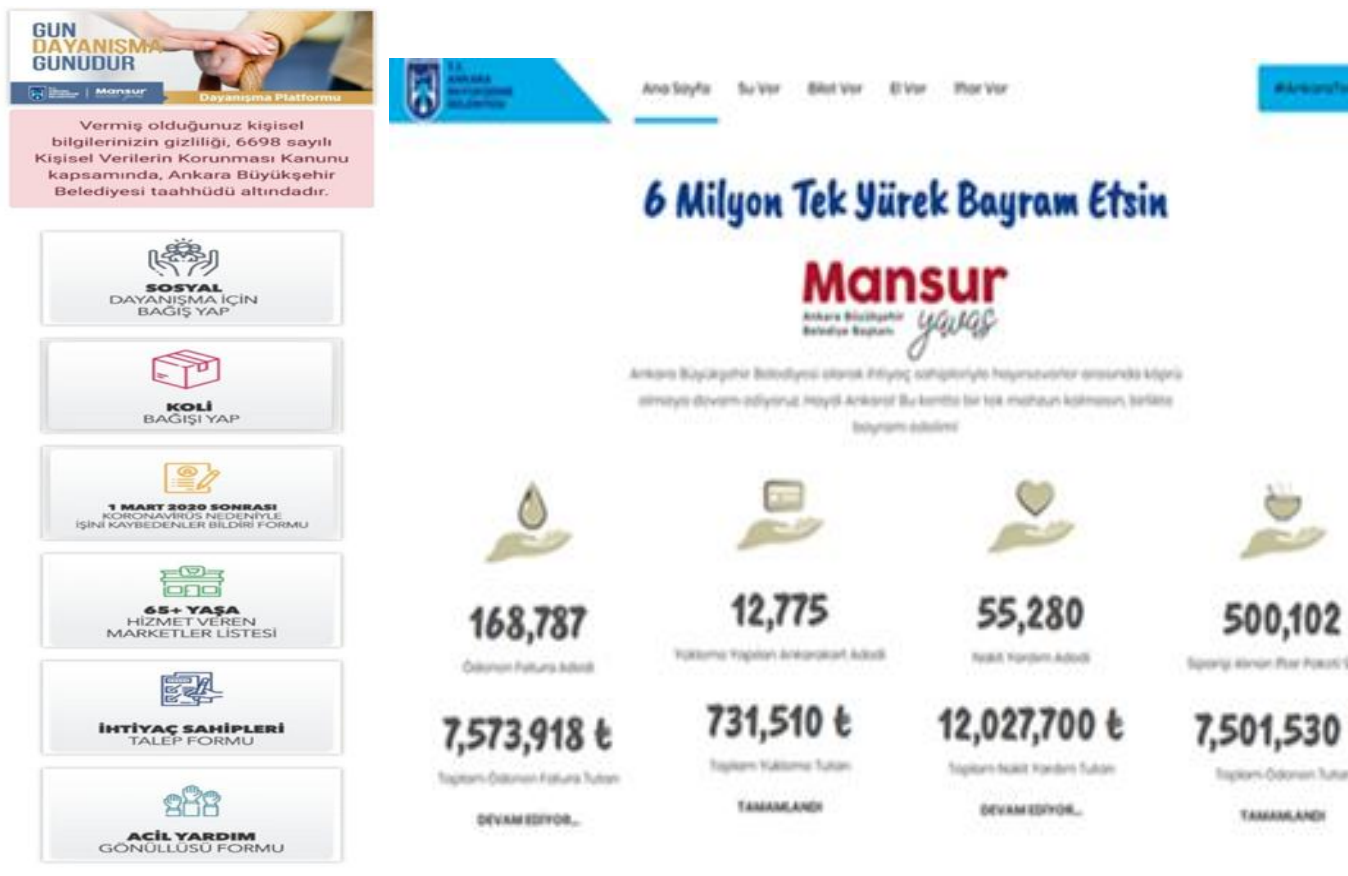

500,102

$7,501,530 \mathrm{t}$ 
Fig. 4. Solidarity Platform II.
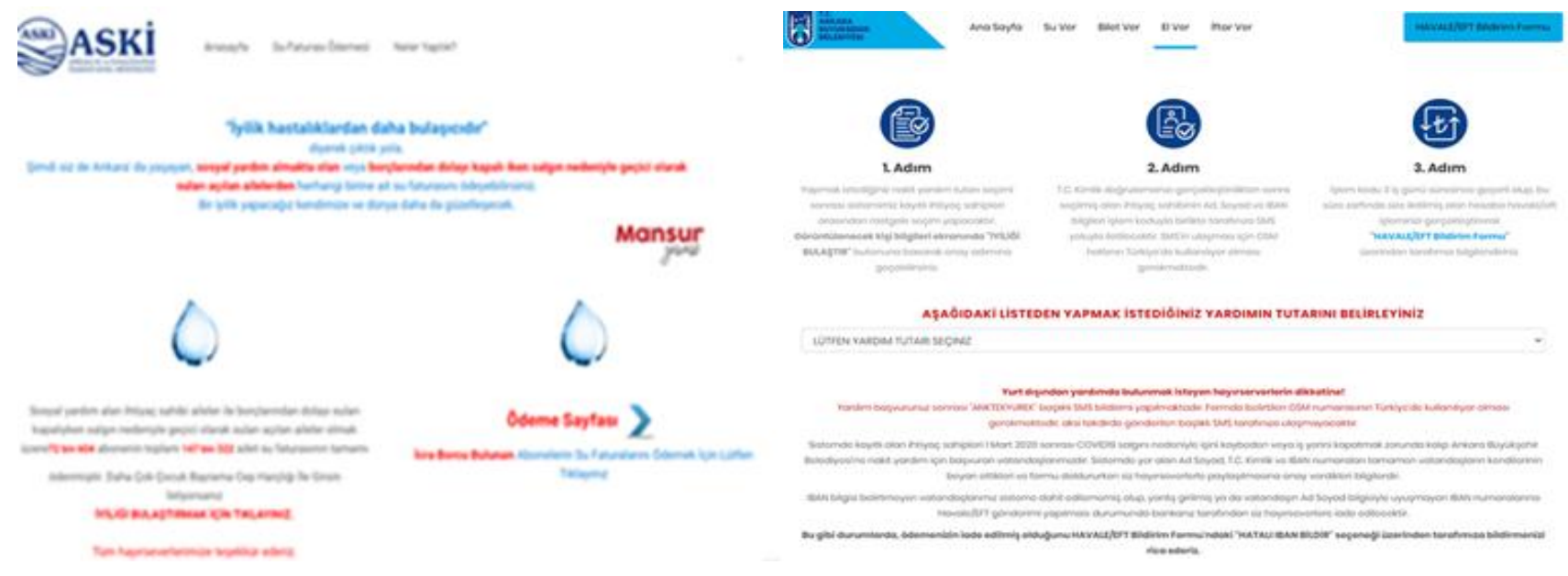

On the homepage, there is a pharmacy list on duty, web TV, disaster and weather report, where is the bus, the transport card balance, ongoing studies, free Wi-Fi areas, online transactions, traffic information and Başkent 153 and emergency notification button that have direct access to the municipal authorities.

Fig. 5. Başkent Mobile Homepage.
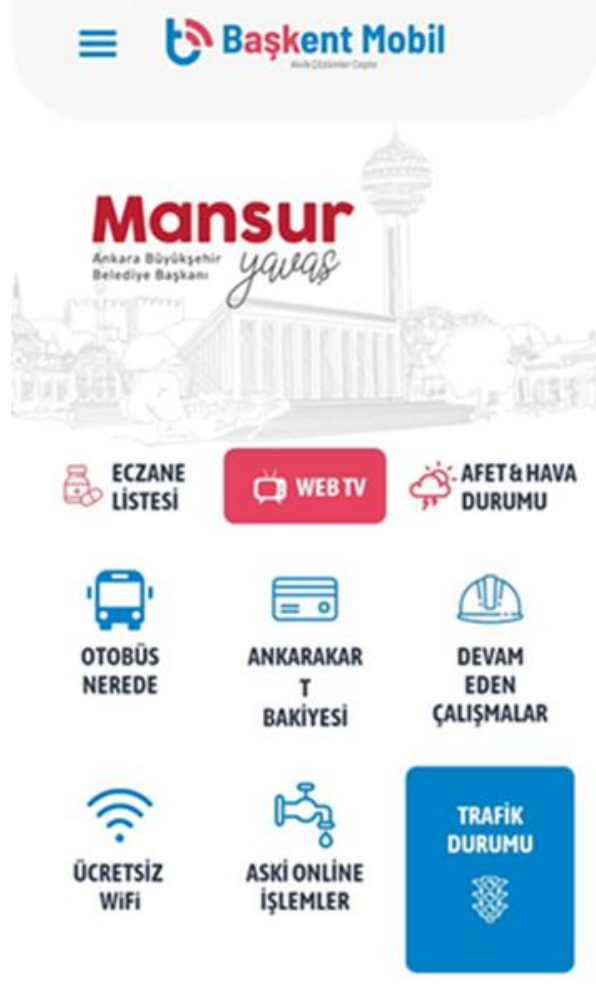

KÜLTÜR ANKARA

Baskent153 $\mathrm{g}^{\prime} \geq \mathrm{Acit}$ Bitoik $=0$

When the Başkent 153 is clicked, a direct call center can be accessed, and a message can be sent from the new application screen and a previous application can be tracked. 
Fig. 6. Başkent 153.

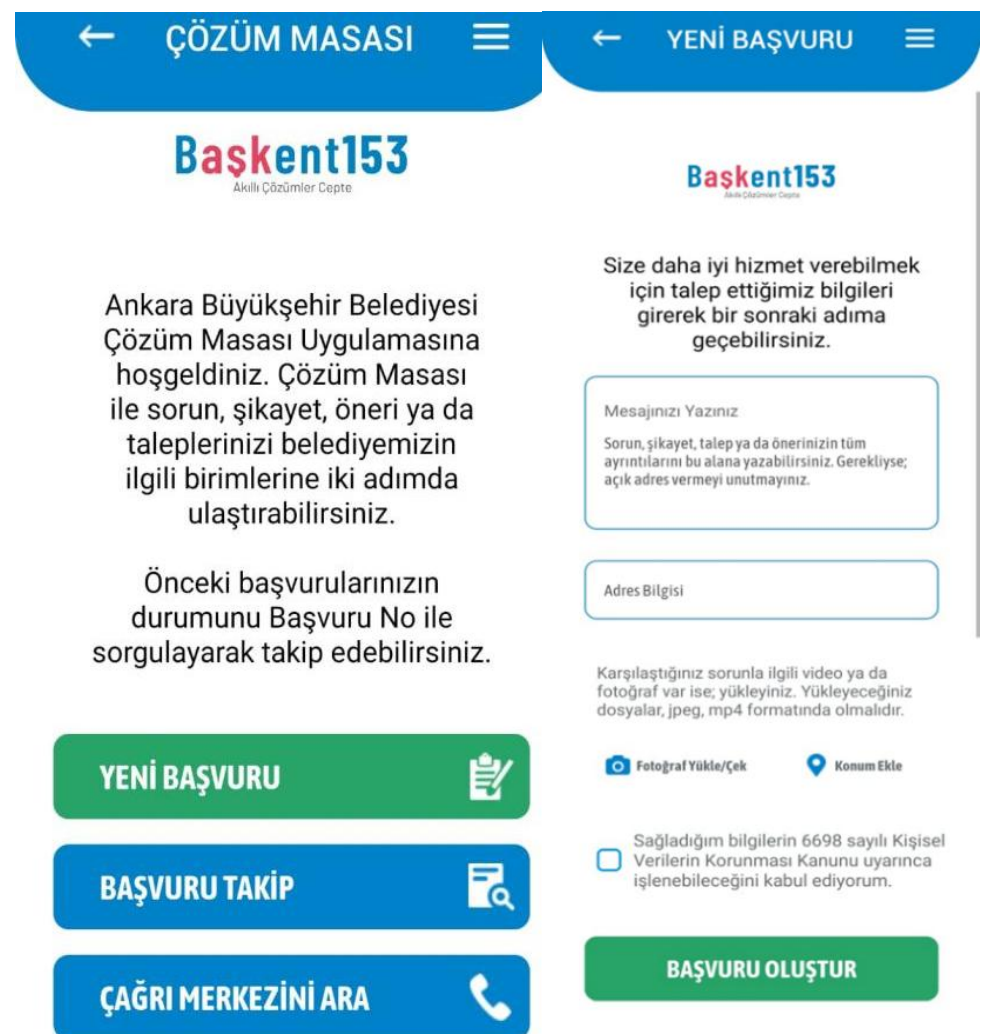

Clicking the emergency report button opens the popup window shown in Fig 5. In addition to the subject title and message, photos and locations can be added. When the application is installed, if you have created a profile and uploaded your personal information, your information can be forwarded to the municipal authorities immediately. Depending on the urgency of your application, the municipality responds. If no action is taken or missing information is given you receive an auto generated SMS.

Fig. 7. Emergency Report Button.

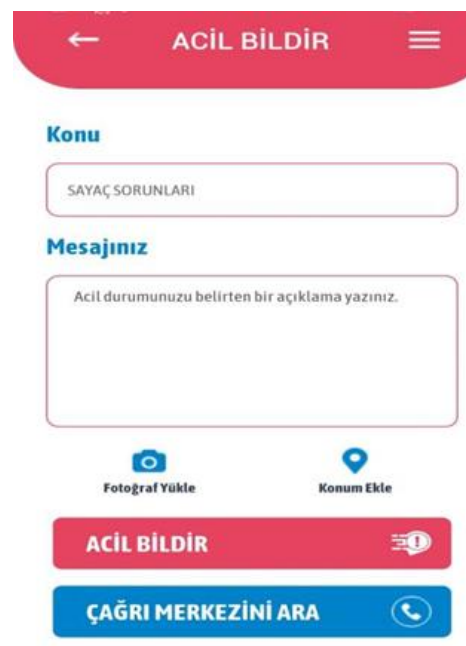

The news, programs, parliamentary meetings and tenders broadcasted live via Web TV are also categorized to be watched later and uploaded to the system and made available to users. 
Fig. 8. Web TV.

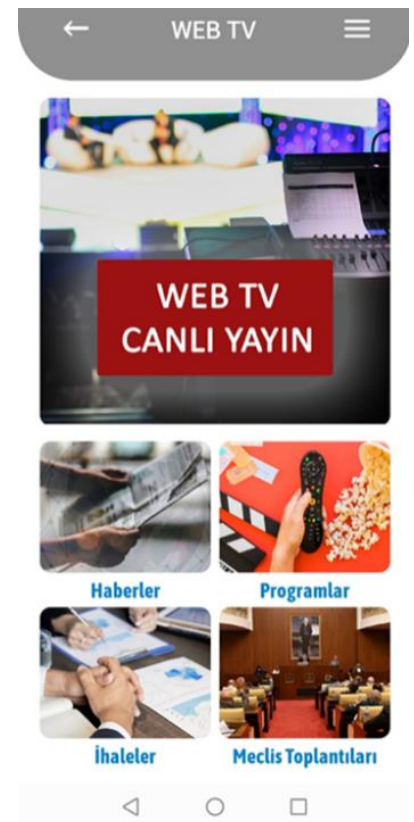

You can search the free Wi-Fi areas of the municipality on the map. You can also search by your current location. By logging on to the application the users can access to the ASKI online menu for available services as well as current weather and traffic information. By switching to the EGO application they can see the live city bus details such as stops, schedules and locations of the busses. Paw Support Application provides opportunities for filing a help request for a street animal and announcement for lost or found pets. The current situation of the lost or found animals are also presented through the application.

Fig. 9. Paw Support App.

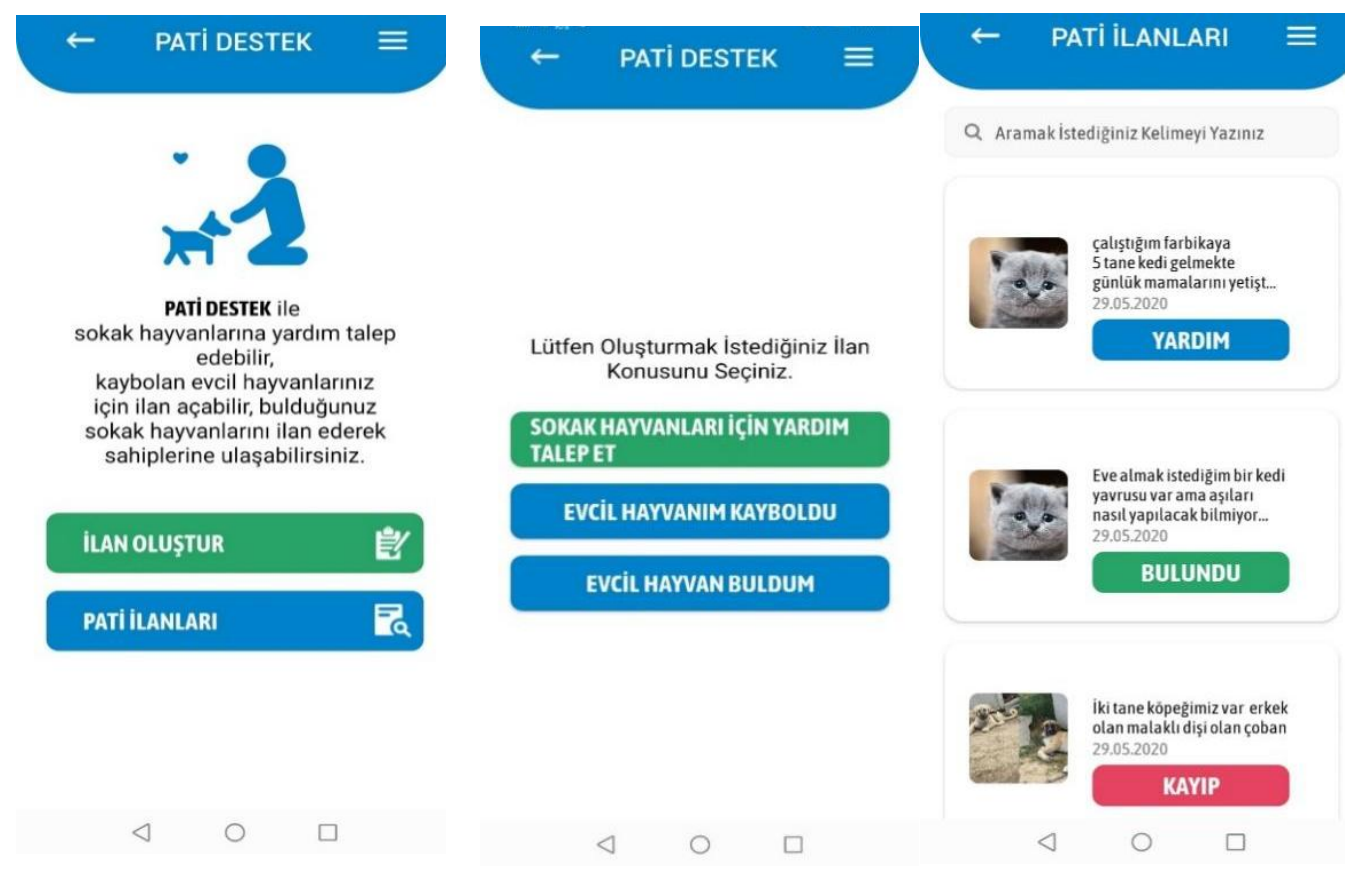

\section{CONCLUSION}

With the digital transformation, the new generation was born into a different world that the prior generations did not know much about and having a hard time getting involved. It seems that the new world is shaped by technological development and has a different lifestyle. Administrations also need to adapt to the requirements of this new lifestyle with necessary transformation. The concepts of e-municipality, m-municipality, and edemocracy have started to take place in our lives, as the process of participation in the administration has 
evolved in the local governments, which are considered as the school of democracy (Y1ldiz T., 2020:2). Yildiz states that the young people's interest in politics is usually lower than the elderly and their interest was further decreased within the last 30 years One of the driving forces behind this gap is the technology. While stating that young people have less confidence in politicians and that they are moving away from representative democracy, he states that there is no room for cumbersome and old-world politics in this dynamic and new world. As a result, the young people are faced with the reality of living a future they could not establish because they could not convey their problems. In this context, the technology, which is thought to keep young people apart from politics can also be used as a method to involve young people in politics. Participating in politics using eparticipation channels may be more attractive to young people than classical participation channels. However, studies should be carried out to ensure that all segments over 65 years of age or similar restricted people to be engaged with technology by remembering the fact that the main purpose of e-participation is to reach broader public audiences and all stakeholders of a democratic society.

Having an infrastructure for e-participation in the municipality's website or mobile application is not enough to really ensure participation. Public participation needs to be taken seriously. The channels for citizens to monitor should also be clear. By seeing the public participation processes affect the results would be motivating for the participants and increase their willingness to participate in future processes.

Ankara Metropolitan Municipality uses various applications to ensure participation as well as opens channels to ensure access to information and services through both web page and mobile application. Başkent 153 provides applications such as Emergency Notification, Click-to-Talk and Paw Support to enable the communication of requests and complaints of reeves and apartment managers. The Solution Desk application serves public to communicate the problems and set the agenda. The participation of the people in the decisions is ensured through surveys on various issues. Determining the name of the Mobile Application and determining the seating arrangement in buses are to name a few. Participation in evaluating practices is followed by watching news, tenders and parliamentary meetings via Web TV. With the Solidarity Platform, the public both participates in the implementation process and participates in evaluating the practices by regularly sharing their current progress. The first phase of the Başkent Mobile application has been implemented and has not been completed yet. With the introduction of the second phase in June, the updated version of the application can be reconsidered.

\section{REFERENCES}

ANKARA METROPOLITAN MUNICIPALITY (2020), “Applications", Corporate Web Page, https://www.ankara.bel.tr/ (Date of access: 03.08.2020).

BARBER, Benjamin (1995), Güçlï Demokrasi (Çev. Mehmet Beşikci), Ayrıntı Yayınları, İstanbul.

BAYONA, Sussy and MORALES, Vicente (2017), "E-Government Development Models for Municipalities", Journal of Computational Methods in Sciences and Engineering, S.17, ss.47-59.

BOJANG, Malang B.S. and BWANDO, William (2018), "E-municipality Applications in Local Government: Prospects and Challenges", 4th International Student Conference, April 3rd-4th 2018, Manisa, Turkey, ss.60-67.

DEMİRAL, Seran (2019), "Dijital Teknoloji Aracılı̆̆ıyla Çocuk Özneleşmesinin Olanakları”, Doğu Batı Dergisi, S.21(86), ss.13-38.

DUDMAN, Jane (2012), "Open Government Partnership: What We're Going to Learn in Brasilia”, The Guardian (16.04), London

ERYILMAZ, Bilal (2019), Kamu Yönetimi, Umuttepe Yayınları, Kocaeli.

GUTIÉRREZ-DIEZ, María del Carmen, PIÑÓN, Howlet Laura Cristina and SAPIÉN, Aguilar Alma Lilia (2018), "Municipality and Open Government: Case Study of Guazapares", International Journal of Management Science and Business Administration, S.4(6), ss.26-33.

GÜRLER HAZMAN, Gülsüm (2005), “Afyonkarahisar Belediyesinde e-Belediye Uygulamalarl ve Yerel Farkındalık”, Afyon Kocatepe Üniversitesi İktisadi ve İdari Bilimler Fakültesi Dergisi, S.1(7), ss.6584. 
UÇAR, Harika ve CANSEL, Arıl - E-Participation in Local Government: Case of Ankara Metropolitan Municipality

GÜRSES, Fatih and ENGIN, Melih (2016), “Türkiye'de Yerel Yönetimlerde Mobil Devlet Uygulamalarl: Büyükşehir Belediyeleri Üzerine Ampirik Bir Araştırma”, Süleyman Demirel Üniversitesi İktisadi ve İdari Bilimler Fakültesi Dergisi, S.1(21), ss.223-234.

HENDEN, H. Burçin and HENDEN, Rıfkı (2005), "Yerel Yönetimlerin Hizmet Sunumlarındaki Değişim ve eBelediyecilik", Elektronik Sosyal Bilimler Dergisi, $\quad$ S.4(14), ss.48-66. https://dergipark.org.tr/tr/pub/esosder/issue/6128/82192 (Date of access: 03.08.2020).

KARACA, Yakup and ÖZTÜRK, Namık Kemal (2019), "Yeni Nesil Belediyecilik: Dijital Belediye Uygulamaları", Uluslararası Yönetim Akademisi Dergisi, S.2(3), ss.528-537.

KAYA BENSGHIR, Türksel (2000), “Web'deki Belediyelerimiz: Ankara Büyükşehir Belediyesi”, Çağdaş Yerel Yönetimler Dergisi, S.9(2), ss.76-90.

KELEŞ, Ruşen (2006), Yerinden Yönetim ve Siyaset, Cem Yayınları, İstanbul.

LEE, Jooho and KIM, Soonhee (2014), "Active Citizen E-Participation in Local Governance: Do Individual Social Capital and E-Participation Management Matter?", 47th Hawaii International Conference on System Sciences, ss.2044-2053, https://ieeexplore.ieee.org/stamp/stamp.jsp?tp=\&arnumber=6758857 (Date of access: 03.08.2020).

LIRONI, Elisa (2016), Potential and Challenges of e-Participation in the European Union, Policy Department C: Citizens' Rights and Constitutional Affairs, European Parliament Publication, Brussels.

MURPHY, Sean, MCLEARTY, Doug and COMMISSO, Tim (2018), "Digital Transformation: a Municipal Game Changer", Amo Conference,

https://www.amo.on.ca/AMOPDFs/Events/18/Presentations/Monday/Digital-Transformation - MNPPresentation-Aug-20-F.aspx (Date of access: 01.03.2019).

ÖKTEM, Mustafa (2005), "Küresel Sistem, Demokratikleşme-Yerelleşme Dinamikleri ve Yerel Demokrasi", Küreselleşme ve Yerelleşme (Ed. Kemal Görmez), Odak Publications, Ankara, ss.23-66.

PALABIYIK, Hamit and GÖRÜN, Mustafa (2004), "Belediye Meclislerinde Temsil ve Katılım: Çanakkale Belediye Meclisi Örneği”, Yerel Yönetimler Kongresi: Dünden Bugüne Yerel Yönetimlerde Yeniden Yapılanma, Çanakkale, ss.257-272.

SCHRODER, Caroline (2014), "A Mobile App for Citizen Participation", International Conference Electronic Governance and Open Society: Challenges in Eurasia: St. Petersburg, Russia, New York: Association for Computing Machinery, https://core.ac.uk/download/pdf/74355687.pdf (Date of access: 03.08.2020).

ŞAT, Nur (2009), "E-Municipality for Citizen-Oriented Administration", International Journal of e-Business $\begin{array}{llll}\text { and e-Government } & \text { Studies, } & \text { S.(1)2, } & \text { ss.27-33, }\end{array}$ https://www.sobiad.org/eJOURNALS/journal_IJEBEG/arhieves/2009/03nur_sat.pdf (Date of access: 03.08.2020).

UÇKAN, Özgür (2003), E-Devlet, E-Demokrasi ve Türkiye, Literature Publishing, İstanbul.

YILDIZ, Mete (2006), “Kamu Siyasaları Açısından Cep Telefonu Teknolojisi ve Mobil Devlet”, Hacettepe Üniversitesi İktisadi ve İdari Bilimler Fakültesi Dergisi, S.24(1), ss.241-263, https://dergipark.org.tr/tr/pub/huniibf/issue/7876/103493 (Date of access: 03.08.2020).

YILDIZ, Mete (2020), “Büyükşehir Ölçeğinde Dijitalleşme ve E-katılım: Ankara Kent Konseyi”, E-Article, https://ankarakentkonseyi.org.tr/sites/akk.turnateknoloji.com/files/2020-09/DIJITALLESME-VEBUYUKSEHIR-METE-YILDIZ-1804-2020.pdf (Date of access: 03.08.2020).

YILDIZ, Mete (No date), "Bilgi Toplumu ve Kaти Yönetimi: e-Devlet Ders Notları, Mobil Devlet”, TUBA Açık Ders Malzemeleri Portalı, https://acikders.tuba.gov.tr/course/view.php?id=67 (Date of access: 03.08.2020).

YILDIZ, Taylan (2020), "Yerel Yönetimlerde Katıllmcl Demokrasi", E-Article, https://ankarakentkonseyi.org.tr/sites/akk.turnateknoloji.com/files/2020-

09/Kat\%C4\%B11\%C4\%B1mc\%C4\%B1-Demokrasi_Taylany\%C4\%B1ld\%C4\%B1z_A4.pdf (Date of access: 03.08.2020). 